\title{
'Jazz at Night and the Classics in the Morning': musical double-consciousness in short fiction by Langston Hughes
}

\author{
Felicia M. Miyakawa
}

Leaders of the Harlem Renaissance-intellectuals such as Jessie Faucet, Alain Locke, James Weldon Johnson and W.E.B. DuBois - hoped to gain respect for African Americans through participation in emblems of high culture such as poetry, novels, serious plays, and the highest of all classical music genres: the symphony. ${ }^{1}$ They encouraged artists to mine folk themes for use in new, elevating works, transforming 'indigenous' materials into uplifting examples of high cultural resonance. Artists themselves, however, were ambivalent about privileging 'high' art, and especially so when making and writing about music. Indeed, as Samuel Floyd has argued, the most vibrant music to come out of the Harlem Renaissance took the form of blues, boogie woogie, and hot jazz, found in venues such as clubs, juke joints, rent parties, and stage shows (Floyd 1990, pp. 5-6).

Writers of the Harlem Renaissance generation, and particularly Langston Hughes, celebrated these vernacular musics in their fiction, finding in blues, jazz, spirituals, and other 'black' musics, not raw materials to be civilised into the shape of high art, but the truest articulation of the 'Negro' experience. In Hughes's own words, jazz is 'one of the inherent expressions of Negro life in America; the eternal tom-tom beating in the Negro soul - the tom-tom of revolt against weariness in a white world' (Hughes 1926, p. 694). For Hughes, jazz and blues best expressed lived experience; the sounds and forms of these musics subsequently permeated his oeuvre.

Hughes also saw in jazz and blues the best hope for bridging the cultural divide between Harlem Renaissance leaders - who reached for the trappings of high, 'white' culture by subjugating their own markers of cultural ethnicity - and average Harlemites - who lived in the world of jazz and blues. This divide between high and low culture seems to parallel W.E.B. DuBois's well-known concept of 'double-consciousness' (Du Bois 1903), a concept Hughes consistently explored throughout his poetry and fiction. Hughes's explorations are at their most powerful, however, when he couches 'double-consciousness' in musical terms, pitting 'black' vernacular musics and modes of musicking, as representative of 'authentic' blackness, against (white) European, classical musical traditions. We see this precise conflict in Hughes's short stories 'Home' and 'The Blues I'm Playing', both from his 1934 collection The Ways of White Folks (Hughes 1934). In these stories, the protagonists - both musicians - must choose one musical tradition over another, 
metaphorically choosing between allegiance to their race and culture and aspiration to 'high' European culture. Ultimately, the contrasting ends these protagonists meet as a result of their musical choices not only reflect their own struggles with 'double-consciousness', but also speak to black music's profound, Orphic power to convey crucial conflicts of racial identity and culture.

$$
* \quad * *
$$

'Home' is the tale of a young musician named Roy who has been in self-imposed exile in Europe for seven or eight years but has now come home to Missouri because he is sick and wants to die with his family. Roy left Missouri as a minstrel and returns to his hometown of Hopkinsville transformed. Violin lessons in Berlin have rendered Roy a virtuoso; he has left jazz behind and now plays classics for his community, classics which neither the black nor white inhabitants of Hopkinsville know or understand. The white community of Hopkinsville, puzzled by Roy's European manners and ability to play European music, sees Roy as an uppity Negro minstrel who is quickly outreaching his prescribed social role. This tension is evident as Roy prepares for and plays his first concert at home. The townspeople hear Roy practising his concert programme of Bach, Beethoven, Massenet and Brahms through the windows of his mother's house and cannot help but comment on the strangeness of Roy's repertoire. Roy, too, is aware of the complex role he now plays in his town. During the concert, and in the grip of fever, Roy discusses the multiple ironies of his performance with (a very dead) Johannes Brahms:

Hello, Mr Brahms on a violin from Vienna at a coloured church in Hopkinsville, Missouri. The slender brown-skin hands of a sick young man making you sing for an audience of poor white folks and even poorer Negroes. Good-evenin', Mr Brahms, a long ways from home, travellin' in answer to your dream, singin' across the world. I had a dream, too, Mr Brahms, a big dream that can't come true, now. (pp. 38-9)

Roy's new virtuosity presents the ultimate irony. Although he now plays his violin well enough to become a concert artist, he will never realise his dream, not simply because he is sick, but because his illness has forced him to return to his segregated home. In Europe such dreams may be possible, but at home in the South, segregation determines and limits possibilities.

Roy finds a single sympathetic soul in Miss Reese, the music teacher at the white high school, who arranges a chamber performance for Roy at the high school and accompanies him. Once again Roy is out of place: 'The students went home that afternoon and told their parents that a dressed-up nigger had come to school with a violin and played a lot of funny pieces nobody but Miss Reese liked' (p. 43). Roy's friendship with Miss Reese is eventually his undoing. As he walks through town late one night dressed in formal concert wear, he meets Miss Reese on the street just as a movie finishes and townspeople spill out of the cinema. Not understanding the nature of the artistic friendship that has sprung up between Roy and Miss Reese, the townspeople lynch Roy for his audacity in talking to a white woman, leaving his body to hang 'like a violin for the wind to play' (p. 48).

Throughout the story, Hughes leaves multiple, conflicting clues to Roy's downfall, which begins long before he returns from Europe. Early signs of Roy's illness appear as he begins to explore European classical music.

For him there had been only a minstrel show to run away with for further education. Then that chance with a jazz band going to Berlin. And his violin for a mistress all the time - with the best 
teachers his earnings could pay for abroad. Jazz at night and the classics in the morning. Hard work and hard practice, until his violin sang like nobody's business. Music, real music! Then he began to cough in Berlin. (p. 45)

At first glance, it would seem that Roy's illness could simply be the result of exhaustion. Extensive travelling and playing his violin day and night not only diffuses his musical identity but also depletes his body of strength. But the emphasis Hughes places on Roy's progression as a musician and subsequent contrasting repertoires suggests a different origin for Roy's illness. Roy privileges his new music and its traditions, preferring to puzzle the citizens of Hopkinsville with his formal concert wear and Bach airs rather than give in to his expected role as a minstrel. Clearly, classical music here is not merely a question of repertoire. In its fullness the music stands for centuries of white European musical and cultural traditions. Once Roy begins to value classical music over his own musical and cultural heritage, he stands to lose a clear sense of himself even as he finds a musical voice. As Roy begins to deny his musical heritage, he coughs. Roy's story can thus be read as a cautionary tale, a warning to black artists and musicians to not abandon their blackness in favour of European cultural respectability. Hughes seems to suggest that abandoning blackness and embracing whiteness, even merely - or perhaps especially - through music, can be deadly.

The toxic nature of white music and white traditions suggested in this story stem from Hughes's belief in jazz as an antidote for the malaise of modern western life, a belief shared by other African-American intellectuals of the 1920s and 1930s. Indeed, Hughes's description of jazz as 'the tom-tom of revolt against weariness in a white world' anticipates an extended description of jazz's power given by Alain Locke a decade later:

Beginning as the primitive rhythms of the Congo ... jazz became more than the Negro's desperate antidote and cure for sorrow. It incorporated the typical American restlessness and unconventionality, embodied its revolt against the drabness of commonplace life, put pagan force behind the revolt against Puritan restraint, and finally became the Western World's life-saving flight from boredom and over-sophistication to the refuge of elemental emotion and primitive vigour. (Locke 1969, p. 90)

Both Locke and Hughes, then, value the transformative nature of jazz: jazz offers redemption from the decadence of western civilisation; gives access to the immediate, the sensual, and the intuitive; and overcomes the intellectual, the mechanical, and the puritan. Even though Hughes resisted the trappings of primitivism in the guise of patronage, in his poetry and fiction he nevertheless promoted an association of essentialist African-American qualities and jazz. And this is Roy's conundrum: having escaped the south via the power of black music, Roy has abandoned his musical inheritance, upsetting the balance of his double musical-self. He falls ill as he loses his grasp on jazz's 'antidote for sorrow', and returns home without the one thing that could have helped him recover: the primitive life force of jazz.

Hughes revisits this theme of the tension between Western art music and Black vernacular music in a more triumphant way with the story of Oceola Jones in 'The Blues I'm Playing'. Oceola, a multi-talented pianist, is supported financially by a wealthy patroness named Mrs Ellsworth. Tension arises quickly between Oceola and Mrs Ellsworth: Mrs Ellsworth supports art for art's sake, whereas Oceola integrates art and daily life. Once in Paris, thanks to Mrs Ellsworth's patronage, Oceola decides 
she cares little for 'art': 'Oceola hated most artists, too, and the word art in French or English. If you wanted to play the piano or paint pictures or write books, go ahead! But why talk about it?' (pp. 109-10). Oceola is Hughes's primitive: she would rather intuit than rationalise, prefers 'playing' to analysing.

Mrs Ellsworth insists Oceola save her fingers for true music and is appalled that Oceola spends her time playing for rent parties and other such casual occasions:

Was it in keeping with genius, [Mrs Ellsworth] wondered, for Oceola to have a studio full of white and coloured people every Saturday night (some of them actually drinking gin from bottles) and dancing to the most tomtom-like music she had ever heard coming out of a grand piano? (pp. 107-8)

Mrs Ellsworth's horrified description of Oceola's musicking uses Hughes's key word in his description of jazz: tomtom. It is not merely that Oceola is not spending enough time practising Chopin études, the trouble is that what she chooses to play in her time off smacks of the primitive. We hear the same descriptors of Oceola's playing as she entertains a crowd at Bricktop's in Paris:

In her playing of Negro folk music, Oceola never doctored it up, or filled it full of classical runs, or fancy falsities. In the blues she made the bass notes throb like tomtoms, the trebles cry like little flutes, so deep in the earth and so high in the sky that they understood everything. (p. 110)

Hughes deftly separates the two musical traditions in this passage. Oceola deliberately avoids any embellishments that may betray her classical training, embellishments here equated with falsity. In contrast, her blues are authentic: they cry like tomtoms and flutes, sure signs of the primitive. Hughes clearly deems the latter a more fitting voice for Oceola.

Eventually Mrs Ellsworth can no longer brook Oceola's artistic 'slumming' and ends her patronage. In their final meeting, Oceola plays for Mrs Ellsworth. She begins with Beethoven and Chopin, but ends with the blues:

her fingers began to wander slowly up and down the keyboard, flowing into the soft and lazy syncopation of a Negro blues, a blues that deepened and grew into rollicking jazz, then into an earth-throbbing rhythm that shook the lilies in the Persian vases of Mrs Ellsworth's music room. Louder than the voice of the white woman who cried that Oceola was deserting beauty, deserting her real self, deserting her hope in life, the flood of wild syncopation filled the house, then sank into the slow and singing blues with which it had begun. (p. 119)

Mrs Ellsworth, misunderstanding Oceola to the end, assumes that playing the blues is not Oceola's true calling and wastes her gifts. But Oceola's persistence in playing 'her' music saves her from Roy's fate. Oceola does not abandon her background, and instead abandons the ways of white folks.

Both Roy and Oceola seem to step from the pages of DuBois's classic, resembling in particular DuBois's description of the crisis of 'double-consciousness' faced by artists:

The innate love of harmony and beauty that set the ruder souls of his people a-dancing and a-singing raised but confusion and doubt in the soul of the black artist; for the beauty revealed to him was the soul-beauty of a race which his larger audience despised, and he could not articulate the message of another people. This waste of double aims, this seeking to satisfy two unreconciled ideals, has wrought havoc with the courage and faith and deeds of ten thousand thousand people, - has sent them often wooing false gods and invoking false means of salvation, and at times has even seemed about to make them ashamed of themselves. (Du Bois 1903, pp. 46-7) 
Hughes places both Roy and Oceola in the midst of this crisis, demanding that they choose just one of the musical traditions. Roy falls to the false brilliance of Western art music, but Oceola is spared; unashamed of her heritage, Oceola chooses the blues over the false salvation of the Western classical tradition.

Hughes is certainly not the first writer to treat jazz and blues as native, vernacular languages of African-American musicians; nor is he the first to locate jazz and blues as sites of both primitivism and authenticity. ${ }^{2}$ Well after the Harlem Renaissance, authors have continued to gravitate towards this powerful trope; stories by James Baldwin, Frank London Brown, Henry Dumas, and LeRoi Jones (Amiri Baraka), to name only a few, all begin with the shared assumption that black music has the power to signify collectivity, sameness, and shared culture. But in 'Home' and 'The Blues I'm Playing', Hughes solidifies black music's signature cultural role by emphasising black music's very opposition to European classical music. In these stories, blues and jazz connect African Americans to tradition and history, whereas Western classical music serves only to isolate African-American musicians from their past, their people, and their authentic selves. In Hughes's hands, the very separateness of African-American vernacular music and European classical traditions becomes a powerful tool, offering a rich way to express the inexpressible and inexplicable double aims of 'double-consciousness'.

\section{Acknowledgments}

An early version of this essay was given at the 2001 joint meeting in Trinidad of the Society for American Music and Center for Black Music Research. I wish to thank my colleagues from these societies who offered comments, questions and encouragement to pursue this project. I would also like to thank John McCluskey and Jeff Magee for their comments and suggestions in the early stages of this project, and Francesca Draughon, Kara Gardner and Mina Yang for their cogent advice as I worked through later drafts of this essay.

\section{Endnotes}

1. See Huggins (1971), Johnson (1927) and Floyd (1990).
2. James Weldon Johnson, for example, took advantage of the same device in his Autobiography of an Ex-Coloured Man (Johnson 1927).

\section{References}

Bruck, P. 1977. 'Langston Hughes: “The blues I'm playing” (1934)', in The Black American Short Story in the 20th Century, ed. P. Bruck (Amsterdam, Oruner)

Chinitz, D. 1977. " "Rejuvenation through joy" - Langston Hughes, primitivism, and jazz', American Literary History, 9/1, pp. 60-78

Du Bois, W.E.B. 1903. The Souls of Black Folk (New York, Penguin; reprint, 1982)

Fabre, G., and Feith, M. (eds.) 2001. Temples for Tomorrow: Looking Back at the Harlem Renaissance (Bloomington and Indianapolis, Indiana University Press)

Floyd, S. (ed.) 1990. Black Music in the Harlem Renaissance: A Collection of Essays (New York, Greenwood Press)

Gilroy, P. 1993. The Black Atlantic: Modernity and Double Consciousness (Cambridge, MA, Harvard University Press)

Huggins, N. 1971. Harlem Renaissance (London, Oxford University Press)

Hughes, L. 1926. 'The negro artist and the racial mountain', The Nation, 122(23 June), pp. 692-4 1934. The Ways of White Folks (New York, Vintage Books; reprint, 1971) 
Johnson, J.W. 1927. The Autobiography of an Ex-Coloured Man, introduction by Carl Van Vechten (New York, Alfred A. Knopf; reprint, 1973)

Jones, L. (Baraka, A.) 1966. 'The myth of a "negro literature" ', in Home: Social Essays (New York, Morrow)

Locke, A. (ed.) 1925. The New Negro: Voices of the Harlem Renaissance (New York, Albert and Charles Boni) 1969 [originally published 1936]. The Negro and his Music and Negro Art: Past and Present (New York, Arno Press and the New York Times)

Olmstead, J. 2000. 'Black moves, white ways, everybody's blues: Orphic power in Langston Hughes' The ways of white folks', in Black Orpheus: Music in African American Fiction from the Harlem Renaissance to Toni Morrison, ed. S. Simawe (New York and London, Garland)

Reini-Grandell, L. 1992. 'Langston Hughes's invocation of the blues and jazz tradition under the double-edged sword of primitivism', West Virginia University Philological Papers, 38, pp. 113-23

Taylor, P. 1972. 'Langston Hughes and the Harlem Renaissance', in The Harlem Renaissance Remembered, ed. A. Bontemps (New York, Dodd and Mead)

Tracy, S. [n.d.] 'Blues to live by: Langston Hughes's "'The blues I'm playing" ', The Langston Hughes Review, $12 / 1$, pp. $12-18$ 